\title{
Small Group Discussion; Medical Students Perspective ${ }^{1}$ Lubna Humayun, ${ }^{1}$ Asma Rasheed, ${ }^{2}$ Muhammad Afaaq Agha \\ ${ }^{1}$ Department of Pathology, University College of Medicine \& Dentistry, University of Lahore \\ ${ }^{2}$ Department of Forensic Medicine \& Toxicology, Shaikh Zayed Medical Complex, Lahore
}

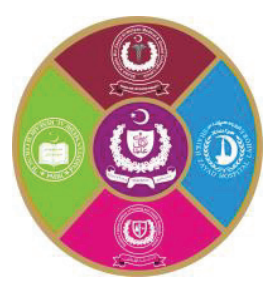

\begin{abstract}
Introduction: Small group discussion teaching is a key instructional strategy being incorporated in medical education and is aimed at enhancing the personal, social and cognitive skills of students. Learning in small groups helps the students to enhance the acquisition, processing and retention of the medical knowledge. Aims \& Objectives: To assess medical student's perception about small group discussion at a medical college. Place and duration of study: September 2019 at the University College of Medicine and Dentistry, University of Lahore. Material \& Methods: This cross- sectional survey was conducted during September 2019 at University College of Medicine and Dentistry, University of Lahore. Convenient sampling technique was used to obtain a sample of 322 students from the first three years of MBBS. A pre validated questionnaire was distributed and the students were asked to record their experience about small group discussion using a 5point Likert scale. Data was analyzed by using SPSS22 and reported as percentage distribution and mean \pm s.d. Results: Regarding quality of these small group discussion sessions, $25.8 \%$ of the students appeared satisfied, $24.8 \%$ of the students were neutral, whereas, $49.4 \%$ of the students remained unsatisfied. When asked about being clear of their role in a SGD session, $55.9 \%$ of the students agreed, $22.7 \%$ were unclear and $21.4 \%$ neutral. As regards the benefits from small group sessions, majority (35.1\%) agreed that activities taught lifelong learning, $8.7 \%$ strongly agreed. $27 \%$ remained neutral with $16.5 \%$ disagreeing and $12.75 \%$ strongly disagreeing. With reference to assessment of tutors, majority of students found SGD facilitators enthusiastic about process with $13.4 \%$ strongly agreeing and $36.3 \%$ agreeing, $28 \%$ stayed neutral while $9.6 \%$ disagreed and $12.75 \%$ strongly disagreed. Majority of students, (35.1\% agreed, $13.4 \%$ strongly agreed) to that tutors just gave mini lecture, $27.6 \%$ responded neutral to statement while $11.2 \%$ disagreeing and $12.7 \%$ strongly disagreeing to the enquiry. Conclusion: The study reveals that majority of the students are clear about their role in small group discussion sessions and majority (35.1\%) also agreed that activities taught them lifelong learning. Tutors are helpful and enthusiastic, however, they provide plenty of information and need retraining for conducting a small group learning session.
\end{abstract}

Key words: Small group discussion, Students' perspective, Teaching, Learning.

\section{INTRODUCTION}

$\mathrm{T}$ raditionally, the undergraduate students of MBBS are divided into small groups to carry out the practical, tutorial and the ward clerkship learning. These small groups function either individually or under the supervision of a facilitator, and usually consist of 8-12 members. In small-group discussion the teacher announces a topic or idea for group discussion among the participants and they conclude the discussion usually in that session. ${ }^{1}$ In the recent years, a number of inadequacies have been recognized in the traditional teaching methods and this has led to major reforms and innovations in the medical education both in the fields of curriculum development as well as teaching strategies. Medical educationists have come to a broad consensus for a need of a shift from the traditional didactic lecturing to the more studentcentered delivery of curriculum. ${ }^{2}$ Research has demonstrated that small group discussion results in greater synthesis and retention of learning materials and the SGD sessions have changed the role of a teacher from a lecturer to a facilitator responsible for the active learning by the students. ${ }^{3,4,5}$

Small group teaching method develops the intellectual skills of the learners such as reasoning, problem solving, the development of attitudes and the acquisition of interpersonal skills such as listening, speaking, arguing and group leadership. ${ }^{6}$ SGDs can take on a variety of different forms such as problem-based learning, case-based learning, role play, discussions, brainstorming sessions and debate sessions. ${ }^{6}$ PBL is a variation of small group discussion strategy where the students define the problem and identify the action steps to create a solution for that problem. It extends over two 
sessions. ${ }^{7}$ Despite the increased use of small group discussion in medical education, relatively little is known about how our students feel about this strategy. ${ }^{8}$ Although, small group teaching holds various advantages but it also poses certain limitations. Teaching in SGDs can be costly because it requires a higher teacher-student ratio. Some teachers find SGD teaching relatively difficult as compared to delivering a long lecture. ${ }^{9}$

In the recent years there has been a shift of curriculum in most of the medical universities from the 'traditional' towards the 'integrated curriculum' and various new modes of information transfer to students have been introduced. Out of these, the small group discussion is the fundamental teaching strategy being incorporated in these medical universities in various ways such as PBL, TBL and CBL sessions. ${ }^{10}$ This is recommended strategy to develop competencies of the students. ${ }^{11}$ With this increase in the use of small group discussion, there is a growing need for research on this strategy. This study is significant as it provides information about the student's perception on the small group discussion sessions.

\section{MATERIAL AND METHODS}

This cross- sectional survey was conducted during September 2019 at University College of Medicine and Dentistry, University of Lahore. The targeted population was the $1^{\text {st }}$ year, $2^{\text {nd }}$ year and $3^{\text {rd }}$ year students of MBBS. The students of the first three years of MBBS who are mainly using SGD as the learning strategy were targeted and the total number of students was 322 .

Inclusion criteria: $1^{\text {st }}$ year, $2^{\text {nd }}$ year and $3^{\text {rd }}$ year students of MBBS students of either gender from the academic year 2018-19.

Exclusion criteria: Students of BDS, post graduate students, those students not willing to participate, incomplete questionnaires were excluded.

Ethical approval: The study was approved by The Ethical Review Board (ERB) University College of Medicine \& Dentistry, under the registration number Ref: ERC/09/19/04. It was conducted among a total of 322 students of the first three years of MBBS who are mainly using SGD as the learning strategy.

Data collection technique: This study was based on pre-validated questionnaire on experience of medical students regarding SGL. The questionnaire that was used contained 19- closed ended questions that addressed the issues related to small group sessions in the integrated curriculum. This questionnaire is an established tool designed by The
Medical Education Department at The King Saud Medical School, and this proforma is available online for general use.

Questionnaire was reviewed by the current research supervisor and was piloted on twenty $2^{\text {nd }}$ year MBBS students. The questionnaire was divided into four subscales and had total 19 items that included closed ended questions that addressed the issues of concern regarding the small group sessions. The questions assessed the structure of the small group learning sessions, the degree of student satisfaction during the process of learning, the assessment of tutors, and the usefulness and the quality of the small group sessions. Students' responses were quantitatively measured in relation to statements on the questionnaire using a five point Likert scale. Strongly disagree (1), Disagree (2), Neutral (3), Agree (4) and Strongly agree (5) The questionnaire was distributed among the participants after filling a consent form and sufficient time was given to each student to properly comprehend and fill it. The students were not required to disclose their names and roll numbers and were assured about the confidentiality of the information they provided in the questionnaire.

\section{Statistical analysis:}

The data was collected by the 19-item questionnaire and the analysis was done on SPSS 22. Data was reported as percentage distribution and standard deviation.

\section{RESULTS}

The results obtained from the study are compiled in Table-1. When asked whether SGL session objectives were made clear, majority of students $(65.2 \%)$ agreed to that, out of this total percentage $26.4 \%$ strongly agreed while $38.8 \%$ agreed. $20.8 \%$ students remained neutral while only $13.9 \%$ disagreed. When asked, if role was made clear to students in SGL session, $42.9 \%$ agreeing while 13\% strongly agreeing to statement. $21.4 \%$ remained neutral while $12.1 \%$ disagreed and $10.6 \%$ strongly disagreeing. When asked about suitability of location and facilities to conduct SGL session, $26.4 \%$ remained neutral with $12.7 \%$ disagreeing and $13.4 \%$ strongly disagreeing. Major percentage $(30.75 \%)$ of students agreeing while $16.8 \%$ strongly agreeing to the statement.

When enquired about their satisfaction levels of small group sessions' progress, 34.5\% students agreed that sessions were thought provoking, 16.1\% strongly agreed while $27.6 \%$ remained neutral. $13 \%$ students disagreed while only $8.7 \%$ strongly 
disagreed to this inquiry. $32.9 \%$ students agreed that sessions led them to active learning, $18.9 \%$ strongly agreed while $25.8 \%$ preferred to remain neutral. $13.4 \%$ thought sessions did not lead to active learning while only $9 \%$ strongly disagreed to this enquiry. When asked if sessions led to deep learning, 31.4\% remained neutral, $25.5 \%$ agreed and $14.9 \%$ strongly agreed while $18.9 \%$ disagreed and only $9.3 \%$ strongly disagreed. Regarding enquiry about sessions helping students to identifying learning needs, only $9 \%$ strongly disagreeing and $14.6 \%$ just disagreeing while $24.2 \%$ preferred to stay neutral. Majority agreed to the statement with $17.4 \%$ strongly agreeing while $34.8 \%$ just agreeing to it. For $31.4 \%$ students agreed, that the small group sessions were easy to look for learning needs while $15.5 \%$ strongly agreed. $11.8 \%$ strongly disagreed, $11.5 \%$ just disagreeing while $29.8 \%$ stayed neutral in this regard.

With regard to assessment of tutors, majority of students found SGD facilitators enthusiastic about process with $13.4 \%$ strongly agreeing and 36.3\% agreeing. $28 \%$ stayed neutral while $9.6 \%$ disagreed and $12.75 \%$ strongly disagreed. Clear majority $(33.9 \%)$ remained neutral when asked if tutors provided lots of information while $14 \%$ thought they did not provide such information and $10.9 \%$ strongly thought against it. $13.7 \%$ students strongly agreed that tutors provided lots of information while 27.65 agreed to it. Majority of students, (35.1\% agreed, $13.4 \%$ strongly agreed to that tutors just gave mini lecture, $27.6 \%$ responded neutral to statement while $11.2 \%$ disagreeing and $12.7 \%$ strongly disagreeing to the enquiry. When asked whether tutors talked a lot in some sessions, $10.9 \%$ disagreed absolutely, $14 \%$ just disagreed while $28.3 \%$ remained neutral. $22.7 \%$ agreed to statement while $16.8 \%$ strongly agreed to the statement.

When asked about benefits from small group sessions, majority (35.1\%) agreed that activities taught them lifelong learning and $8.7 \%$ strongly agreed. $27 \%$ remained neutral with $16.5 \%$ disagreeing while $12.75 \%$ strongly disagreeing to this query. 32\% students found sessions important and thought they will be of use in future and 16.8\% strongly agreed. Small percentage i.e., 9.95\% disagreed, $10.2 \%$ strongly disagreed to it while significant $31.1 \%$ preferred to comment neutral. $37 \%$ agreed and $11.8 \%$ strongly agreed that these activities helped them to improve ability to think and solve problems rather than just memorizing information, where as $13.7 \%$ disagreed and $8.1 \%$ disagreed with $29.5 \%$ staying neutral about this question. $41.6 \%$ students agreed, while $12.1 \%$ strongly agreed that these activities helped them to develop skills in working as member of a team. $11.2 \%$ disagreed, $9.3 \%$ strongly disagreed while $25.8 \%$ students commented neutral in this respect. Majority of students i.e., 36.5\% agreeing, 16.1\% strongly agreeing to statement that these activities improved their abilities to communicate effectively, $26.1 \%$ stayed neutral while $13 \%$ disagreed and $8.7 \%$ strongly disagreed. When enquired about sessions improving leadership skills, $16.8 \%$ disagreed, $10.2 \%$ strongly disagreed and $28 \%$ opted to stay neutral. $28.9 \%$ agreed while $16.1 \%$ strongly agreed that sessions improved their leadership skills.

$36 \%$ students agreed while $13.4 \%$ strongly agreed that they were satisfied with quality of these sessions with $12.1 \%$ disagreeing, $13.7 \%$ strongly disagreeing to this statement. $24.8 \%$ students stayed neutral in this regard.

\begin{tabular}{|c|c|c|c|c|c|}
\hline Items & \begin{tabular}{|l|} 
Strongly \\
disagree
\end{tabular} & Disagree & Neutral & Agree & \begin{tabular}{|c|} 
Strongly \\
Agree
\end{tabular} \\
\hline \multicolumn{6}{|c|}{ Structure of small group discussion sessions } \\
\hline $\begin{array}{l}\text { 1. The SGD session objectives } \\
\text { were made clear to me }\end{array}$ & $\begin{array}{c}22 \\
(6.8 \%)\end{array}$ & $\begin{array}{c}23 \\
(7.1 \%) \\
\end{array}$ & $\begin{array}{c}67 \\
(20.8 \%) \\
\end{array}$ & $\begin{array}{c}125 \\
(38.8 \%)\end{array}$ & $\begin{array}{c}85 \\
(26.4 \%) \\
\end{array}$ \\
\hline $\begin{array}{l}\text { 2. My role was made clear to } \\
\text { me in the SGD session }\end{array}$ & $\begin{array}{c}34 \\
(10.6 \%) \\
\end{array}$ & $\begin{array}{c}39 \\
(12.1 \%) \\
\end{array}$ & \begin{tabular}{|c|}
69 \\
$(21.4 \%)$ \\
\end{tabular} & $\begin{array}{c}138 \\
(42.9 \%) \\
\end{array}$ & $\begin{array}{c}42 \\
(13 \%) \\
\end{array}$ \\
\hline $\begin{array}{l}\text { 3. The location and facilities } \\
\text { were suitable for the } \\
\text { conduction of sessions }\end{array}$ & $\begin{array}{c}43 \\
(13.4 \%)\end{array}$ & $\begin{array}{c}41 \\
(12.7 \%)\end{array}$ & $\begin{array}{c}85 \\
(26.4 \%)\end{array}$ & $\begin{array}{c}99 \\
(30.75 \%\end{array}$ & $\begin{array}{c}54 \\
(16.8 \%)\end{array}$ \\
\hline \multicolumn{6}{|c|}{ Satisfaction of small group discussion sessions' progress } \\
\hline $\begin{array}{l}\text { 4. The sessions were thought } \\
\text { provoking }\end{array}$ & $\begin{array}{c}28 \\
(8.7 \%) \\
\end{array}$ & $\begin{array}{c}42 \\
(13 \%) \\
\end{array}$ & \begin{tabular}{|c|}
89 \\
$(27.6 \%)$ \\
\end{tabular} & $\begin{array}{c}111 \\
(34.5 \%) \\
\end{array}$ & $\begin{array}{c}52 \\
(16.1 \%) \\
\end{array}$ \\
\hline $\begin{array}{l}\text { 5. The sessions led me to } \\
\text { active learning }\end{array}$ & $\begin{array}{c}29 \\
(9 \%)\end{array}$ & $\begin{array}{c}43 \\
(13.4 \%)\end{array}$ & $\begin{array}{c}83 \\
(25.8 \%) \\
\end{array}$ & $\begin{array}{c}106 \\
(32.9 \%)\end{array}$ & $\begin{array}{c}61 \\
(18.9 \%)\end{array}$ \\
\hline $\begin{array}{l}\text { 6. The sessions led me to deep } \\
\text { learning process }\end{array}$ & $\begin{array}{c}30 \\
(9.3 \%)\end{array}$ & $\begin{array}{c}61 \\
(18.9 \%) \\
\end{array}$ & $\begin{array}{c}101 \\
(31.4 \%) \\
\end{array}$ & $\begin{array}{c}82 \\
(25.5 \%) \\
\end{array}$ & $\begin{array}{c}48 \\
(14.9 \%) \\
\end{array}$ \\
\hline $\begin{array}{l}\text { me to } \\
\text { ning needs }\end{array}$ & \begin{tabular}{c|}
29 \\
$(9 \%)$ \\
\end{tabular} & $\begin{array}{c}47 \\
(14.6 \%) \\
\end{array}$ & $\begin{array}{c}78 \\
(24.2 \%) \\
\end{array}$ & $\begin{array}{c}112 \\
(34.8 \%) \\
\end{array}$ & $\begin{array}{c}56 \\
(17.4 \%) \\
\end{array}$ \\
\hline $\begin{array}{l}\text { o look for the } \\
\text { ds }\end{array}$ & $\begin{array}{c}38 \\
(11.8 \%)\end{array}$ & $\begin{array}{c}37 \\
(11.5 \%)\end{array}$ & $\begin{array}{c}96 \\
(29.8 \%) \\
\end{array}$ & $\begin{array}{c}101 \\
(31.4 \%) \\
\end{array}$ & $\begin{array}{c}50 \\
(15.5 \%)\end{array}$ \\
\hline \multicolumn{6}{|l|}{ Assessment of Tutors } \\
\hline $\begin{array}{l}\text { 9. SGD facilitators were } \\
\text { enthusiastic about the } \\
\text { process }\end{array}$ & $\mid \begin{array}{c}41 \\
(12.75 \%)\end{array}$ & $\begin{array}{c}31 \\
(9.6 \%)\end{array}$ & $\begin{array}{c}90 \\
(28 \%)\end{array}$ & $\begin{array}{c}117 \\
(36.3 \%)\end{array}$ & $\begin{array}{c}43 \\
(13.4 \%)\end{array}$ \\
\hline $\begin{array}{l}\text { 10. The tutors provided us } \\
\text { lots of information }\end{array}$ & $\begin{array}{c}35 \\
(10.9 \%)\end{array}$ & $\begin{array}{c}45 \\
(14 \%)\end{array}$ & $\begin{array}{c}109 \\
(33.9 \%)\end{array}$ & $\begin{array}{c}89 \\
(27.6 \%)\end{array}$ & $\begin{array}{c}44 \\
(13.7 \%) \\
\end{array}$ \\
\hline itors gave us a mini- & $\begin{array}{c}41 \\
(12.7 \%)\end{array}$ & $\begin{array}{c}36 \\
(11.2 \%) \\
\end{array}$ & $\begin{array}{c}89 \\
(27.6 \%) \\
\end{array}$ & $\begin{array}{c}113 \\
(35.1 \%) \\
\end{array}$ & $\begin{array}{c}43 \\
(13.4 \%) \\
\end{array}$ \\
\hline $\begin{array}{l}\text { 12. The tutors were talking a } \\
\text { lot in some of the sessions }\end{array}$ & $\begin{array}{c}35 \\
(10.9 \%) \\
\end{array}$ & $\begin{array}{c}69 \\
(21.4 \%) \\
\end{array}$ & $\begin{array}{c}91 \\
(28.3 \%) \\
\end{array}$ & $\begin{array}{c}73 \\
(22.7 \%) \\
\end{array}$ & $\begin{array}{c}54 \\
(16.8 \%) \\
\end{array}$ \\
\hline \multicolumn{6}{|c|}{ Benefits from small group discussion sessions } \\
\hline $\begin{array}{l}\text { 13. The activities taught me } \\
\text { lifelong learning }\end{array}$ & $\begin{array}{c}41 \\
(12.75 \%) \\
\end{array}$ & $\begin{array}{c}53 \\
(16.5 \%) \\
\end{array}$ & $\begin{array}{c}87 \\
(27 \%) \\
\end{array}$ & $\begin{array}{c}113 \\
(35.1 \%) \\
\end{array}$ & $\begin{array}{c}28 \\
(8.7 \%) \\
\end{array}$ \\
\hline $\begin{array}{l}\text { 14. What I learned in these } \\
\text { sessions was important } \\
\text { and will be of use to me in } \\
\text { the future }\end{array}$ & $\begin{array}{c}33 \\
(10.2 \%) \\
\end{array}$ & $\begin{array}{c}32 \\
(9.95 \%)\end{array}$ & $\begin{array}{c}100 \\
(31.1 \%)\end{array}$ & $\begin{array}{c}103 \\
(32 \%)\end{array}$ & $\begin{array}{c}54 \\
(16.8 \%)\end{array}$ \\
\hline $\begin{array}{l}\text { 15. These activities helped me } \\
\text { improve my ability to } \\
\text { think and solve problems } \\
\text { rather than just } \\
\text { memorizing information }\end{array}$ & $\begin{array}{c}26 \\
(8.1 \%)\end{array}$ & $\begin{array}{c}44 \\
(13.7 \%)\end{array}$ & $\begin{array}{c}95 \\
(29.5 \%)\end{array}$ & $\begin{array}{c}119 \\
(37 \%)\end{array}$ & $\begin{array}{c}38 \\
(11.8 \%)\end{array}$ \\
\hline $\begin{array}{l}\text { 16. These activities helped me } \\
\text { to develop skills in work- } \\
\text { ing as a member of a team }\end{array}$ & $\begin{array}{c}30 \\
(9.3 \%)\end{array}$ & $\begin{array}{c}36 \\
(11.2 \%)\end{array}$ & $\begin{array}{c}83 \\
(25.8 \%)\end{array}$ & $\begin{array}{c}134 \\
(41.6 \%)\end{array}$ & $\begin{array}{c}39 \\
(12.1 \%)\end{array}$ \\
\hline $\begin{array}{l}\text { 17. These activities improved } \\
\text { my ability to } \\
\text { communicate effectively }\end{array}$ & $\begin{array}{c}28 \\
(8.7 \%)\end{array}$ & $\begin{array}{c}42 \\
(13 \%)\end{array}$ & $\begin{array}{c}84 \\
(26.1 \%)\end{array}$ & $\begin{array}{c}116 \\
(36.5 \%)\end{array}$ & $\begin{array}{c}52 \\
(16.1 \%)\end{array}$ \\
\hline
\end{tabular}




\begin{tabular}{|l|c|c|c|c|c|}
\hline $\begin{array}{l}\text { 18. These sessions improve } \\
\text { my leadership skills }\end{array}$ & $\begin{array}{c}33 \\
(10.2 \%)\end{array}$ & $\begin{array}{c}54 \\
(16.8 \%)\end{array}$ & $\begin{array}{c}90 \\
(28 \%)\end{array}$ & $\begin{array}{c}93 \\
(28.9 \%)\end{array}$ & $\begin{array}{c}52 \\
(16.1 \%)\end{array}$ \\
\hline $\begin{array}{l}\text { 19. Overall, I was satisfied } \\
\text { with the quality of these } \\
\text { sessions }\end{array}$ & $\begin{array}{c}44 \\
(13.7 \%)\end{array}$ & 39 & 80 & 116 & 43 \\
\hline Mean & $(12.1 \%)$ & $(24.8 \%)$ & $(36 \%)$ & $(13.4 \%)$ \\
\hline Standard deviation & 63.68 & 42.84 & 87.68 & 102.63 & 49.37 \\
\hline
\end{tabular}

Table-1: Undergraduate Medical student's perception about small group discussion sessions at the University College of Medicine, University of Lahore.

\section{DISCUSSION}

According to this study the medical students found SGD a better learning methodology and are generally satisfied with the small group discussion sessions in the integrated curriculum. Students have difficulty in remaining attentive during lectures and usually cannot retain the knowledge effectively in long lectures. This study found that small group discussions give a chance of active participation to all the learners and they feel more in control of the learning process. The findings are similar to those from study by Pradeep et $\mathrm{al}^{12}$ in which students showed interest in the small group discussion methodology as it enhanced their intellectual skills such as reasoning, problem-solving, and critical thinking.

Similar studies carried out in Shifa College of Medicine Islamabad, ${ }^{13}$ Malaysia $^{14}$ and the University of Sharjah ${ }^{15}$ all have agreed that the students find the SGDs to be the most effective strategy for learning and they are satisfied with the teacher's role in a SGD. In contrast, the present study found $35.1 \%$ of the medical students are dissatisfied with the teachers' role in SGD and believed that tutors gave mini-lectures in these sessions. The teachers actively participate in teaching the topic to the students and forget their passive role of a facilitator who just has to guide the learners if they go astray from the topic. It is suggested that proper and frequent training sessions and workshops should be arranged for the faculty members so that they conduct the SGD sessions in true spirit.

This research will effectively contribute towards the implementation of strategies that would improve the conduction of SGD sessions. The results of this study will help to understand the student attitudes towards small group work, effectiveness of group dynamics and assessing the role of tutors in this teaching strategy.

For future research, small group discussion sessions should also be assessed during all phases of medical education, from undergraduate clinical training to postgraduate residency education, it would be worthwhile to also measure the perceptions of teachers regarding small group teaching and compare the perceptions of teachers and students to gain a better understanding. Moreover, it would also be valuable to measure the effectiveness of SGD in a more rigorous fashion, assessing the effects it has on a student's educational progress and professional development. ${ }^{16,17}$ It will be better if we could repeat the study and identify the trend of student feedback about the SGDs over years.

\section{CONCLUSION}

The study reveals that the students found these sessions to be interactive and friendly and they bridged the gap between the teacher and student. The negative perception of the students is about the role of teachers during the sessions as they are providing too much information during the SGD. The tutors should leave it up to the learners to attain the learning objectives. The investigator strongly recommends that at institutional level this mode of learning should be used as routine method at appropriate intervals for teaching medical students.

\section{REFERENCES}

1. Edmunds S, Brown G. Effective small group learning: AMEE Guide No. 48. Med Teach [Internet]. 2010 Sep 26; 32(9):715-26. Available from:http://www.tandfonline.com/doi/full/10.31 09/0142159X.2010.505454

2. Wijnen M, Loyens SMM, Smeets G, Kroeze M, van der Molen $\mathrm{H}$. Comparing problem-based learning students to students in a lecture-based curriculum: learning strategies and the relation with self-study time. Eur J Psychol Educ. 2017 Jul 1; 32(3):431-47.

3. Hamann K, Pollock PH, Wilson BM. Assessing Student Perceptions of the Benefits of Discussions in Small-Group, Large-Class, and Online Learning Contexts. College Teaching, 2012 v60 n2 p65-75.

4. Silva $\mathrm{AB} \mathrm{Da}$, Bispo ACK de A, Rodriguez DG, Vasquez FIF. Problem-based learning: A proposal for structuring PBL and its implications for learning among students in an undergraduate management degree program. Rev Gestão. 2018; 25(2):160-77.

5. Chang BJ. Problem-based learning in medical school: A student's perspective. Vol. 12, Annals of Medicine and Surgery. Elsevier Ltd; 2016. p. $88-9$. 
6. Annamalai N, Manivel R, Palanisamy R. Small group discussion: Students perspectives. Int J Appl Basic Med Res. 2015; 5, Suppl S1:18-20.

7. Elaine H.J. Yew, Karen Goh. Problem- Based Learning: An overview of its Process and Impact on learning. Health Professions Education. 2016; 2(2): 75-79.

8. Hameed, S., Khalid, T., Aslam, S., Ahmad, M., Farhan, F., Batool, Z., \& Hamid, S. (2017). Team Based Learning In Pathology Effect On Test Scores And Student Satisfaction. Pakistan Armed Forces Medical Journal, 67(3), 423-28.

9. Mirza AUB, Khan RA, Zia S, Iqbal Y. Medical students' perspective about factors motivating participation in small group discussions. JPMA 64: 1339; 2014

10. Yew EHJ, Goh K. Problem-Based Learning: An Overview of its Process and Impact on Learning. Heal Prof Educ. 2016 Dec 1;2(2):75-9

11. Raut DSS, Shreechakradhar U DM, More DSR, Rathod DVS, Gujar DVM, Nardele D V., et al. Developing Competencies of Medical Students Using Group Discussion as TL Method. IOSR J Dent Med Sci. Volume 13, Issue 1 Ver. IV (Jan. 2014), PP 24-27.

12. Sahu P, Nayak S, \& Rodrigues V. Medical students' perceptions of small group teaching effectiveness in hybrid curriculum. Journal of Education and Health Promotion. 2018; 7(1),30.

13. Ahmad RN, Bhatti MM, Khan AH, Ghayur S, Rafi S, Naseem S, et al. Small group discussion as a learning strategy for medical undergraduates. Rawal Med J. 2014; 39(3):344-348.

14. Aziz N, Nasir R, Salam A. Students' perception of small group teaching: A cross sectional study. Middle East J Fam Med. 2008;6(5) 37-39

15. Mousa Abu Ghoush, Mohammed Abdul Qadir,
Zaharaa Al-Lami, Safa Al-Abdullah, Nihar Dash. Undergraduate Medical Students' Perception about Learning in Small Group at University of Sharjah. Journal of Health Science. 4 (2016); 207-214.

16. Steinert Y. Student perceptions of effective small group teaching. Med Educ [Internet]. 2004 Mar; 38(3):286-93.

17. Soliman MM, Alnassar SA. Student perception of small group teaching in first year MBBS at King Saud University Medical College Saudi Arabia. Pak J Med Sci 2011; 27(5):963-966.

\section{The Authors:}

Dr. Lubna Humayun

Assistant Professor,

Department of Pathology,

University College of Medicine and Dentistry, The University of Lahore.

Dr. Asma Rasheed

Assistant Professor,

Department of Pathology,

University College of Medicine and Dentistry,

The University of Lahore.

Dr. Muhammad Afaaq Agha

Assistant Professor,

Department of Forensic Medicine \&Toxicology, Shaikh Zayed Medical Complex, Lahore.

\section{Corresponding Author:}

Dr. Lubna Humayun

Assistant Professor,

Department of Pathology,

University College of Medicine and Dentistry,

The University of Lahore.

Email: lubnahumayun155@gmail.com 